\title{
SMITHSONIAN INSTITUTION RADIOCARBON MEASUREMENTS II
}

\author{
AUSTIN LONG \\ Radiation Biology Laboratory, Smithsonian Institution \\ Washington, D. C. 20560
}

These analyses were performed from November 1963 to November 1964 with equipment and techniques essentially unchanged since the previous date list. Unless otherwise noted all samples were submitted by Smithsonian staff members, each of whom was most helpful in supplying information pertaining to the samples and in discussion of results.

\section{SAMPLE DESCRIPTIONS}

I. ARCHAEOLOGICAL SAMPLES

\section{A. Eastern United States}

\section{SI-127. Hirsh Mound, Bath County, Virginia}

$$
\begin{array}{r}
920 \\
\text { A.D. } 1030
\end{array}
$$

Charcoal from hearth in burial mound in Bath County $\left(38^{\circ} 05^{\prime} \mathrm{N}\right.$ Lat, $79^{\circ} 50^{\prime} \mathrm{E}$ Long), associated with occasional Radford potsherd and triangular projectile point in the mound fill. Coll. 1962 by C. G. Holland; subm. by Clifford Evans.

\section{SI-128. Davis Farm, Virginia}

$$
\begin{array}{r}
1300 \\
\text { A.D. } 650
\end{array}
$$

Charcoal from Davis Farm village site $\left(37^{\circ} 43^{\prime} \mathrm{N}\right.$ Lat, $78^{\circ} 20^{\prime}$ Long), associated with both Stony Creek and Albemarle pottery. Depth 10 to 30 in. Coll. 1962 by Holland; subm. by Evans. Seriation analysis by Evans places site in Middle Woodland Period, in transition between Stony Creek and Albemarle pottery types.

\section{SI-129. Pulaski County, Virginia}

$350 \pm 200$

\section{A.D. 1600}

Charcoal from 1 to $2 \mathrm{ft}$ depth at Site PU-3 $\left(37^{\circ} 12^{\prime} \mathrm{N}\right.$ Lat, $80^{\circ} 36^{\prime} \mathrm{W}$ Long). Pottery seriation by Evans of this site with others in the area places site in Late Woodland, in transition between Radford and New River pottery types. Coll. 1963 by Holland; subm. by Evans.

\section{SI-130. Pulaski County, Virginia}

$620 \pm 120$

A.D. 1330

Charcoal from 1.5 to $2.0 \mathrm{ft}$ depth at Site PU-9 $\left(37^{\circ} 09^{\prime} \mathrm{N}\right.$ Lat, $80^{\circ} 32^{\prime} \mathrm{W}$ Long), associated with Wythe net and knot roughened pottery, all pre-Radford, according to seriation analysis by Evans. Coll. 1963 by Holland; subm. by Evans. Comment: earliest pottery found to date in SW Virginia.

\section{SI-131. Lee County, Virginia}

A.D. 1210

$740 \pm 130$

Charcoal from Site LE-17B ( $36^{\circ} 37^{\prime} \mathrm{N}$ Lat, $83^{\circ} 14^{\prime} \mathrm{W}$ Long), 1.5 to 2.0 ft depth. Pottery associated with sample does not fit seriation of this SW Vir- 
ginia area, being almost entirely New River and Lee Linear Complicated Stamped wares. Presumably of Late Woodland age. Coll. 1963 by Holland; subm. by Evans.

\section{Bowman series, Virginia}

Charcoal from refuse pits at Bowman site on bank of Cedar Creek $\left(39^{\circ} 00^{\prime}\right.$ $\mathrm{N}$ Lat, $78^{\circ} 19^{\prime} \mathrm{W}$ Long), Shenandoah County; should indicate age of Keyser Cord-marked pottery type, the only type found at this site. Coll. 1963 by H. A. MacCord; subm. by Evans.
SI-135. Feat. 8
$240 \pm 120$
SI-136. Feat. 6
A.D. 1710
A.D. 1640
$\mathbf{3 1 0} \pm \mathbf{1 2 0}$
A.D. 1590
$360 \pm 120$
SI-137. De Shazo site, Virginia

Charcoal from Feat. 3, $1 \mathrm{ft}$ depth, De Shazo site $\left(38^{\circ} 15^{\prime} \mathrm{N}\right.$ Lat, $77^{\circ} 16^{\prime}$ W Long), King George County. Should date Rappahannock Fabric-impressed pottery type. Brass bead found in same pit. This may be site of Cuttatawoman on Smith's map of Virginia based on his 1608 explorations of Rappahannock River Valley. Coll. 1964 by MacCord; subm. hy Evans.

\section{SI-138. Irwin site, Virginia}

$$
\begin{array}{r}
910 \pm 120 \\
\text { A.D. } 1040
\end{array}
$$

Charcoal from Feat. 3, 14 in. depth at Irwin site $\left(37^{\circ} 15^{\prime} \mathrm{N}\right.$ Lat, $77^{\circ} 22^{\prime}$ W Long), Prince George County. Should indicate age of Stony Creek and Chickahominy pottery types in central Virginia. Coll. 1964 by MacCord; subm. by Evans.

\section{B. Central United States}

\section{SI-59. Molstad site, South Dakota}

$$
360 \pm 50
$$

A.D. 1590

Wooden post butt from Site 39DW234 (45 $27^{\prime} 30^{\prime \prime}$ N Lat, $100^{\circ} 20^{\prime} 45^{\prime \prime}$ W Long), Dewey County. Sample No. 1698 from S part of Feat. 10, E of House 2. Chouteau Aspect $0.85 \mathrm{ft}$ below surface, above aeolian loess layer. Coll. 1962 by J. J. Hoffman; subm. by R. W. Neuman. Comment: date agrees with A.D. $1475 \pm 100$ (SI-25, Smithsonian I).

\section{Red Willow Reservoir series, Nebraska}

Charcoal samples from three sites in Red Willow and Frontier County. Coll. 1962 by R. T. Grange, Jr.; subm. by M. F. Kivett and Grange, Nebraska State Hist. Soc.

SI-68. Site 25RW28

$$
\begin{array}{r}
1430 \\
\text { A.D. } 530
\end{array}
$$

$\left(40^{\circ} 20^{\prime} 41^{\prime \prime} \mathrm{N}\right.$ Lat, $100^{\circ} 28^{\prime} 42^{\prime \prime} \mathrm{W}$ Long) . Sample No. 52, fill and floor of Feat. 8, large basin-shaped house pit. House and fill both from Woodland Period.

SI-70. Site 25FT54

$$
640 \pm 50
$$

$\left(40^{\circ} 23^{\prime} 36^{\prime \prime} \mathrm{N}\right.$ Lat, $100^{\circ} 44^{\prime} 47^{\prime \prime}$ W Long). Samples No. 1557, 1558, 
1554, 1560 combined, from refuse deposit in Area B, 0.5 to $1.0 \mathrm{ft}$ depth. Comment (W.R.W.) : Central Plains Phase; a few sherds may be related to Over Focus, South Dakota.

SI-72. Site 25Ft80

$$
440 \pm 40
$$

$\left(40^{\circ} 22^{\prime} 50^{\prime \prime} \mathrm{N}\right.$ Lat, $100^{\circ} 43^{\prime} 52^{\prime \prime} \mathrm{W}$ Long). Feat. 1, refuse in storage pit. Central Plains Phase.

\section{Lower Cheyenne River series, South Dakota}

Stanley County $\left(44^{\circ} 46^{\prime} \mathrm{N}\right.$ Lat, $100^{\circ} 43^{\prime} \mathrm{W}$ Long), Site 39STl. Juniper post samples associated with or above long-rectangular houses of Thomas Riggs Focus. Coll. 1951 and 1955 and subm. by W. R. Wedel.

\section{SI-116. No. 3161}

$$
\begin{array}{r}
800 \\
\text { A.D. } 1150
\end{array}
$$

Feat. 5, Area 3, a long rectangular house. Comment: another section from same $\log$ was dated at A.D. $1600 \pm 85$ (I-582, unpub. date). The A.D. 1150 date is more consistent with archaeological context and with most of previously obtained $\mathrm{C}^{14}$ dates in area.

\section{SI-117. (USNM No. 422229)}

$$
\text { A.D. } 1160
$$

$790 \pm 60$

Feat. 102 in house Feat. 34, a long rectangular house. Comment: same post was previously dated at A.D. $1175 \pm 125$ (I-581, Isotopes III) and A.D. $920 \pm 60$ (SI-12, Smithsonian I). Present analysis confirms Isotopes date and earlier analysis from this lab. should be disregarded.

SI-118. (USNM No. 422230)

$$
\begin{array}{r}
870 \pm 60 \\
\text { A.D. } 1080
\end{array}
$$

Feat. 103 in house Feat. 34. Comment: same post was dated previously at A.D. $1300 \pm 200$ (M-840, Michigan V) and A.D. $1080 \pm 60$ (SI-17, Smithsonian I). Present number substantiates previous one from this lab.

SI-119. No. X-90

$610 \pm 100$

From midden stratigraphically above floor of Feat. 34 (see SI-117, 118, above).

\section{Medicine Creek Reservoir series}

Samples of unburned wood, probably Juniper, from Site $25 \mathrm{FT} 13\left(40^{\circ} 18^{\prime}\right.$ N Lat, $100^{\circ} 13^{\prime} 52^{\prime \prime}$ W Long), in Frontier County, Nebraska. Coll. 1948 by Kivett and Metcalf; subm. by Wedel.

\section{SI-87. USNM No. 431811, Feat. 1}

0 to $18 \mathrm{in}$. depth below surface. Comment: another sample from this feature dates A.D. $1440 \pm 100$ (I-584, Isotopes III).

SI-88. USNM No. 432143, Feat. 30

$$
\begin{array}{r}
940 \pm 60 \\
\text { A.D. } 1010 \\
270 \pm 60
\end{array}
$$

\section{SI-89. Tiber Reservoir Site, Montana}

No. 24TL26-1959 charcoal from Sec. V, Feat. 3 (hearth) $\left(48^{\circ} 31^{\prime}\right.$ N Lat, 
$11^{\circ} 30^{\prime} \mathrm{W}$ Long), Toole County, Montana. Sample is from excavation of hunting camp of unknown association or age.

\section{La Roche series, South Dakota}

Samples from Chouteau Aspect circular houses at Site 39ST9 (44. 13' 20" N Lat, $99^{\circ} 55^{\prime} \mathrm{W}$ Long), South Dakota. Coll. 1963 by Hoffman; subm. by Neuman.

\section{SI-95. (No. 54) Charcoal}

\section{SI-97. (No. 76) Juniper post butt}

\section{SI-104. (No. 61) Wooden post butt}

\section{Area A, House 3, Post 185}

$\mathbf{2 7 0} \pm \mathbf{5 0}$ A.D. 1680

A.D. 1660

$$
290 \pm 60
$$

A.D. 1520

$1.2 \mathrm{ft}$ to $1.8 \mathrm{ft}$ below surface. Sample from early, circular house, representing early La Roche Culture.
SI-105. (No. 82) Charred wood from Juniper roof beam $\mathbf{5 7 0} \pm \mathbf{5 5}$ Area E, House 2, Feat. 25

$1.03 \mathrm{ft}$ to $1.81 \mathrm{ft}$ below datum. Sample dates a circular house component which directly overlies a rectangular house component.

\section{SI-106. (No. 69) Charcoal Area B, House 4, Feat. 10 (cache pit) A.D. 1640 \\ $310 \pm 55$}

Charcoal collected from all levels of cache pit, $0.5 \mathrm{ft}$ to $3.0 \mathrm{ft}$ below surface. Comment (R.W.N.) : tree ring dates by George Will in 1947 from this site give A.D. 1445, 1450, 1460, 1465. These dates were based upon a master chart for the Bismark, North Dakota area and are in question, since extension of master chart this far away may not be fully applicable.

\section{SI-73. Frontier County, Nebraska}

$820 \pm 50$

Wood post fragments from Site 25FT17 (No. USNM 433503) $\left(40^{\circ} 23^{\prime}\right.$ $\mathrm{N}$ Lat, $100^{\circ} 14^{\prime} \mathrm{W}$ Long). Feat. 70 , depth 20 to $24 \mathrm{in}$. SE center post. Coll. 1948 by Kivett, Metcalf; subm. by Wedel. Comment: wood from same house unit as SI-34 (A.D. $465 \pm 65$, Smithsonian I), which did not agree with consistent dates of A.D. 1085 to A.D. 1240 (SI-32, SI-36, SI-40, SI-47, Smithsonian I), on similar Upper Republican cultural materials. Present date bears out anomaly of SI-34.

\section{SI-75. Fanning site, Kansas}

Charred corn from bottom of Cache Pit 3, Site 14DP1 $\left(39^{\circ} 51^{\prime} \mathrm{N}\right.$ Lat, $95^{\circ} 9^{\prime} 30^{\prime \prime}$ W Long). Doniphan County. Coll. 1963 by W. M. Bass, Jack Schock; subm. by Wedel. Comment: maximum age is on $2 \sigma$ criterion, including only counting uncertainty. Comment (W.R.W.) : on archaeological and historical evidence, site was occupied between ca. 1650 and 1750. 


\section{SI-45. Lamb Spring site, Colorado}

Bison bone fragments, unburned, from bison bone bed in Site 5DO201 (39 $30^{\prime} \mathrm{N}$ Lat, $105^{\circ} 4^{\prime} \mathrm{W}$ Long), in Douglas County, ca. 8 mi S of Littleton, Colorado. Associated with bone bed were Eden and Scottsbluff points similar to those found at Horner site. Coll. 1962 by Wedel and Metcalf; subm. by Wedel. Comment: see discussion of Horner site, SI-74, below.

\section{SI-74. Horner site, Wyoming}

$7880 \pm 1300$ 5930 в.c.

Charcoal from Site 48PA29 (44. $33^{\prime} 45^{\prime \prime}$ N Lat, $109^{\circ} 49^{\prime}$ W Long), Park County, ca. 4 mi NE of Cody, Wyoming. Sample is from stratum bearing Eden and Scottsbluff points, and bones of more than 500 bison. Site has yielded much definite Yuma Complex cultural material. Coll. 1952 by F. Goto and Roy Phillips; subm. by Wedel. Comment: large standard deviation is due to unusually small size of sample. Other dates from site are $6876 \pm 250$ B.P. (C-302, burned bone) and $6920 \pm 500$ (C-795, charcoal) (Libby, 1955), and $8840 \pm 140$ (UCLA 697 B, charred bone) (Berger et al., 1964).

\section{Carbon County series, Montana}

Charcoal samples from Site 24CB221, a small rock shelter on Big Horn River ( $45^{\circ} 08^{\prime} \mathrm{N}$ Lat, $108^{\circ} 10^{\prime} \mathrm{W}$ Long). Coll. 1963 by W. M. Husted; subm. by Neuman.

\section{SI-98. Feat. 14}

$8690 \pm 100$ 6740 B.c.

Shallow, circular firepit in brown sand. Top of firepit $0.1 \mathrm{ft}$ below upper surface of brown sand. Agate basin artifacts were found in brown sand.

\section{SI-101. Feat. 15 (No. 210)}

$8600 \pm 100$ 6650 в.c.

Shallow, oval firepit in brown sand. Top of firepit is 0.1 to $0.2 \mathrm{ft}$ below upper contact of brown sand.

\section{SI-99. Feat. 5}

$$
\begin{array}{r}
1050 \\
\text { A.D. } 900
\end{array}
$$

Oval, basin-shaped firepit. Pit is younger than brown sand. Comment: large corner-notched point in firepit suggests Late Middle Prehistoric.

\section{SI-100. Feat. 3}

$$
1070 \pm 70
$$

\section{A.D. 880}

Deep, circular, rock-filled firepit, associated with upper cultural level. Comment: associated artifacts indicate Late Prehistoric Period.

\section{Barry's Landing series, Big Horn River, Montana}

Two charcoal samples from shallow, oval firepits in two small rock shelters on right bank of Big Horn River ( $45^{\circ} 08^{\prime} \mathrm{N}$ Lat, $108^{\circ} 10^{\prime} \mathrm{W}$ Long), Big Horn County, Montana. Associated artifacts indicate Late Prehistoric Period. Coll. 1963 by Husted; subm. by Neuman. 
SI-102. No. 24BH251-38

Feat. 2 in upper cultural level. Comment: age is definitely pre-Late Prehistoric.

\section{SI-103. No. 24BH253-97}

Feat. 5 in only occupation noted in site.

\section{SI-114. Tuktu site, Brooks Range, Alaska}

$$
1280 \pm 55
$$$$
\text { A.D. } 670
$$

$6510 \pm 610$

Charred long bone fragments from Anaktuvuk Pass $\left(68^{\circ} 12^{\prime} \mathrm{N} \mathrm{Lat,} 151^{\circ}\right.$ $36^{\prime}$ W Long). Hearth area No. 1, 4 to 8 in. depth in gravels of kame terrace. Associated with Tuktu complex artifacts. See Campbell (1961). Coll. 1959 and subm. by J. M. Campbell, Dept. of Anthropol., Univ. of New Mexico, Albuquerque. Comment: date supports hypothesis that Tuktu complex predates Denbigh Flint Complex.

\section{SI-86. Walnut Canyon, Arizona}

$3880 \pm 96$ 1930 в.c.

Wood (probably Salix sp.) from split twig figurines from cave in $\mathrm{N}$ wall of Walnut Canyon near Walnut Canyon Natl. Monument $\left(35^{\circ} 10^{\prime} \mathrm{N} \mathrm{Lat} 111^{\circ}\right.$ $30^{\prime}$ W Long). Samples NA5607.9, NA5607.14 and NA5607.23 combined. Coll. 1963 and subm. by A. P. Olson, Mus. of Northern Arizona, Flagstaff. Comment: other dates on similar figurines: $3530 \pm 300$ B.P. (M-563, Michigan II), $3100 \pm 110$ B.P. (A-47, Arizona I).

\section{Mexico}

\section{SI-124. Purron Dam (Tr 15), Mexico}

$2750 \pm 60$

800 в.c.

Charcoal from silt and sand filling spillway of dam $1.0 \mathrm{~km} \mathrm{~S}$ of Purron Cave ( $18^{\circ} 10^{\prime} \mathrm{N}$ Lat, $97^{\circ} 07^{\prime} \mathrm{W}$ Long), Tehuacan Valley, Puebla, Mexico. Coll. 0 to $18 \mathrm{~cm}$ above plastered floor of spillway against E wall. Coll. 1964 by R. B. Woodbury and J. A. Neely; subm. by Woodbury. Comment (R.B.W.) : dam represents beginning of large-scale irrigation in Mesoamerica.

\section{Valdivia series}

\section{E. South America}

Charcoal and shell (all Anomalocardia subrugosa) from midden and associated with pottery sequence of Valdivia culture determined by Evans and Meggers. Site G-31 ( $1^{\circ} 56^{\prime} \mathrm{S}$ Lat, 80 45’ W Long), Guayas Province, Ecuador. Subm. by Clifford Evans.

General Comment (C.E.) : a detailed discussion of the meaning of a large series of dates from Valdivia Phase and Machalilla Phase of Early Formative Period of Coastal Ecuador is given in Meggers, Evans and Estrada (1965).

\section{SI-112. Charcoal}

$3350 \pm 200$ $1400 \mathrm{B.C}$.

Cut J, Zone D, level 3.90 to $4.20 \mathrm{~m}$. Should date earliest part of period A of Valdivia culture. Comment: sample was small and finely-divided and was 
not pretreated; result should be thus considered a minimum age. Stratigraphi-

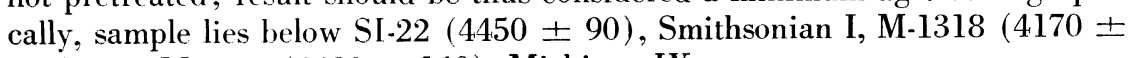

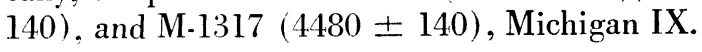
SI-81.
(No. 336) Shell
$4270 \pm 60$

Cut A, level 2.00 to $2.20 \mathrm{~m}$. Coll. 1956 by Estrada. Middle Period A.

SI-83. (No. 334) Shell

$4530 \pm 55$

Cut A, level 1.60 to $1.80 \mathrm{~m}$. Coll. 1956 by Estrada. Late Period A.
SI-84. (No. 315) Shell
$4390 \pm 60$
2440 в.c.
SI-84 R. (replicate analysis)
$4540 \pm 50$

Cut H, level 1.30 to $1.40 \mathrm{~m}$. Coll. 1957 by Evans and B. J. Meggers. Late Period B. Comment: two analyses are in agreement.
SI-85.
(No. 314) Shell
$4170 \pm 65$
2220 B.c.

Cut H, level 1.20 to $1.30 \mathrm{~m}$. Coll. 1957 by Evans and Meggers. Middle to Late Period B.
SI-80.
(No. 309) Shell
$4140 \pm 60$
2190 в.C.

Cut H, level 0.20 to $0.40 \mathrm{~m}$. Coll. 1957 by Evans and Meggers. Early Period C.

\section{SI-78. (No. 312) Shell}

$3970 \pm 65$ 2020 в.c.

0.80 to $1.00 \mathrm{~m}$. Coll. 1957 by Evans and Meggers. Early Period C.

\section{SI-82. (No. 335) Shell \\ $4120 \pm 65$}

Cut A, level 1.80 to 2.00 m. Coll. 1956 by Estrada; subm. by Evans. Middle to Late Period A.

\section{Buena Vista series}

Shell (Anomalocardia subrugosa) from midden and associated with pottery of Valdivia culture periods as determined by pottery analysis of Evans and Meggers. Site G-54 ( $1^{\circ} 56^{\prime} \mathrm{S}$ Lat, $80^{\circ} 44^{\prime} \mathrm{W}$ Long), Guayas Province, Ecuador. Coll. 1961 by Evans and Meggers; subm. by Evans.

\section{SI-71. (No. 1157-8)}

Cut 1, level 1.00 to $1.30 \mathrm{~m}$. Late Period C.

SI-69. (No. 1155)

Cut 1, level 0.60 to $0.80 \mathrm{~m}$. Late Period C.

\section{SI-67. La Cabuya, Ecuador}

Shell (Anomalocardia subrugosa) from midden of Site G-110 ( $1^{\circ} 58^{\prime} \mathrm{S}$ Lat, $80^{\circ} 45^{\prime} \mathrm{W}$ Long), Guayas Province, associated with pottery of Machalilla 
Culture (Meggers and Evans, 1962). No. 1191, cut 2, level 0.20 to $0.40 \mathrm{~m}$. Machalilla Culture is contemporary with Later Period C of Valdivia Culture. Coll. 1961 by Evans and Meggers; subm. by Evans.

\section{La Cabuya series}

Two samples of charred food clinging to pot sherds from Site G-110 (See SI-67 above). Associated sherds belong to Machalilla Culture.

\section{SI-107. Cut 2, Level 0 to $20 \mathrm{~cm}$ \\ $3320 \pm 170$ \\ 1370 в.с. \\ SI-108. Cut 2, Level 20 to $40 \mathrm{~cm}$ \\ $2980 \pm 160$ \\ 1030 в.c.}

Comment (C.E.) : sherds were from same vessel even though in slightly different, but adjacent strata; hence discrepancy between two dates must be explained in other terms than the association. Best estimate would be an average of the two samples for level 0 to $40 \mathrm{~cm}$, cut 2 or $3150 \pm 160$ B.P. Shell sample from cut 2, level 20 to $40 \mathrm{~cm}$ gave date of $2830 \pm 45$ (SI-67, this paper).

\section{Guadalupe Mound Complex, Venezuela}

Two charcoal samples from Cut 6 in external mound E-1 $\left(10^{\circ} \mathrm{N}\right.$ Lat, $69^{\circ}$ $40^{\prime}$ W Long), District of Jimenez, State of Lara. Both samples associated with cultivated maize. Coll. 1953 and subm. by Mario Sanoja, Dept. of Anthropol., Univ. of Andes, Marida, Venezuela.

\section{SI-120. Depth $120 \mathrm{~cm}$ (level 6)}

$$
\mathbf{3 8 0} \pm \mathbf{5 0}
$$

Represents first known appearance of cultivated maize in northern South America.

\section{SI-121. Depth 0 to $20 \mathrm{~cm}$ (level 2)}

$\mathbf{3 8 0} \pm \mathbf{5 0}$

Represents last occupation of this mound.

A.D. 1570

\section{Parana series, Brazil}

Charcoal samples from 2 archaeological excavations in state of Parana, related to appearance of pottery at each site. Coll. 1964 by Igor Chmyz; subm. by Evans.

$$
\begin{array}{lrrr}
\text { SI-139. } & \text { (No. 01) } 0.75 \text { to } 0.30 \mathrm{~m} & \mathbf{3 1 0} \pm \mathbf{5 0} \\
& & \text { A.D. } 1640 \\
\text { SI-140. } & \text { (No. 02) } 0.15 \text { to } 0.30 \mathrm{~m} & 760 \pm 50
\end{array}
$$

Rio Paranapanema Valley, Municipio de Cambara $\left(22^{\circ} 55^{\prime} \mathrm{S}\right.$ Lat, $50^{\circ}$ W Long). SI-139 has only chipped stone artifacts with it; SI-140 is above nonceramic zone and is associated with painted pottery and a relatively small amount of coiled and corrugated ware. Comment: this lab. finds no technical explanation for age reversal, but considering consistency of SI-140, 141, 142, it is apparently SI-139 which is in error, and presumably represents intrusion of younger material into the section.

SI-141. (No. 03) 0.10 to $0.20 \mathrm{~m}$

$$
\begin{array}{r}
800 \pm 50 \\
\text { A.D. } 1150
\end{array}
$$


SI-142. (No. 04) 0.04 to $0.50 \mathrm{~m}$

A.D. 1220

Rio Vermelho Valley, Municipio de Uniāo da Vitoria $\left(26^{\circ} 8^{\prime} \mathrm{S}\right.$ Lat, $51^{\circ}$ W Long). SI-142 is associated with non-ceramic material and SI-141 is from a pottery containing horizon.

$$
\text { F. Asia and Pacific }
$$

\section{SI-125. Mitaka, Japan $\quad 5090 \pm 6$}

Charcoal from International Christion Univ, 3140 в.c. $31^{\prime} 40^{\prime \prime}$ E Long), Mitaka City, Tokyo, Jan associated with Atamadai and Kakyo, Japan, from Location 21 in humus layer of gravel. Coll. 1964 by J. Kiddsusaka pottery types and overlain by $85 \mathrm{~cm}$ consistent with early Middle Kidder, Jr.; subm. by Evans. Comment: result is $\begin{array}{ll}\text { SI-93. Honshu Island, Japan } & \mathbf{4 5 8 0} \pm 60 \\ & \mathbf{2 6 3 0} \text { B.c. }\end{array}$

Charcoal from floor of house No. 13, Oomiyama site (ca. $35^{\circ} \mathrm{N}$ Lat, ca. 148 E Long), Nagano Prefecture. Coll. 1961 by Ichiro Yawata of Archaeol. Lab., Tokyo Univ. of Education; subm. by Evans. Sample is from Middle Jomon Period pit house. Only other Middle Jomon date is from shell midden in Ubayama, $4570 \pm 150$ B.P. (UCLA-279, UCLA III). Comment (C.E.) : agrees with estimate and other dates of similar pottery complex.

\section{SI-113. Tang Buddha, China $\quad 1440 \pm 5$}

Wood chips from arm of a dry lacquer Buddhist image about life size. Image assigned to Tang Dynasty (A.D. 618-906) on basis of stylistic evidence alone. Subm. by R. J. Gettens, Freer Gallery of Art. Comment: wood is probably Cryptomeria; thus the particular tree rings dated may predate the image by 100 or $200 \mathrm{yr}$.

\section{Ponape series}

Specimens of charcoal from trench in N side of mound of Site P-2: Idehd, Ponape, Caroline Islands $\left(6^{\circ} 50^{\prime} 17^{\prime \prime} \mathrm{N}\right.$ Lat, $158^{\circ} 20^{\prime} 15^{\prime \prime} \mathrm{E}$ Long). Samples are from ash midden where ceremonial fires were made using basalt columns and coral to form a hearth. Thus there is possibility of contamination with burnt organic material from fossil coral. In light of consistency of the numbers obtained from $\mathrm{C}^{14}$ analysis, possibility considered minimal. Samples coll. 1963 by Evans, Meggers and S. H. Riesenberg; subm. by Evans.

\begin{tabular}{cccc} 
Sample No. & \multicolumn{2}{c}{ Location coordinates } \\
& $\begin{array}{c}\text { Meters in from } \\
\text { base of mound }\end{array}$ & $\begin{array}{c}\text { Meters from } \\
\text { surface }\end{array}$ & Date \\
\hline SI-90 & $\mathbf{3 . 5 0}$ & $\mathbf{1 . 2 0}$ & $\mathbf{5 2 0} \pm \mathbf{6 5}$ \\
SI-91 & $\mathbf{8 . 5 0}$ & $\mathbf{1 . 4 7}$ & A.D. $\mathbf{1 4 3 0} \mathbf{6 9 0} \pm \mathbf{5 0}$ \\
& & & A.D. $\mathbf{1 2 6 0}$ \\
SI-92 & $\mathbf{8 . 0 0}$ to 8.50 & $\mathbf{2 . 2 5}$ to $\mathbf{2 . 4 5}$ & $\mathbf{7 7 0} \pm \mathbf{6 0}$
\end{tabular}


Comment (C.E.) : dates fall in line according to stratigraphic order and seem reasonable in light of ethnological information for Ponape and Caroline Islands.

II. GEOLOGIC SAMPLES

\section{SI-28. Gladstone Creek, Alaska}

$$
370 \pm 120
$$

Cracked bone (moose or caribou) near Gladstone Creek $\left(61^{\circ} 21^{\prime} \mathrm{N}\right.$ Lat, $138^{\circ} 10^{\prime} \mathrm{W}$ Long). Associated with stone scrapers and projectile heads of possible Taye Lake culture. Coll. 1962 and subm. by D. B. Krinsley, U. S. Geol. Survey, Washington, D. C.

\section{Kluane Lake series, Yukon Territory}

Peat from terrace $32 \mathrm{ft}$ above Kluane Lake $\left(61^{\circ} 21^{\prime} \mathrm{N}\right.$ Lat, $138^{\circ} 45^{\prime} \mathrm{W}$ Long), at Dog Head Point associated with layer $5 \mathrm{~cm}$ thick of wind-borne ash. Coll. 1962 and subm. by Krinsley.

SI-110. Immediately above ash

$$
\begin{aligned}
& 510 \pm 60 \\
& \text { A.D. } 1440 \\
& 1280 \pm 60
\end{aligned}
$$

SI-111. Immediately below ash

Birch Creek, Alaska series

Samples from alluvium of Birch Creek $\left(65^{\circ} 42^{\prime} 30^{\prime \prime} \mathrm{N}\right.$ Lat, $144^{\circ} 22^{\prime} \mathrm{W}$ Long). All dipping $17^{\circ}$ as result of Pingo updoming. Coll. 1963 and subm. by Krinsley.

\section{SI-122. (63-54 A) Fibrous peat}

$5720 \pm 65$

3770 в.c.

1.77 to $1.85 \mathrm{~m}$ below top of bluff. Comment: date is maximum for updoming of Pingo.

\section{SI-123. (63-54 E) Wood chips}

$6950 \pm 400$

$2.77 \mathrm{~m}$ below top of bluff.

\section{SI-115. Monterey Bay, California}

Skull bone of Hydrodamalis steller (extinct) dredged from bottom of Monterey Bay ( $37^{\circ} \mathrm{N}$ Lat, $122^{\circ}$ W Long ) . Coll. 1962 by R. E. Jones, Univ. of California, Davis; subm. by Remington Kellogg. All historically recorded occurrences of this species are in vicinity of Bering lsland in Bering Sea.

\section{SI-109. Willeox Playa, Arizona}

$10,110 \pm 400$

Mollusc shell composed of Sphaerium, Gyraulus, Lymnaea (Fossaria), Succinea, Vertigo (id. by E. J. Roscose, Chicago Mus. Natl. Hist.). Sample from alt 4173 to $4174.5 \mathrm{ft}$ in excavation $\mathbb{W}$ of beach ridge on $\mathbb{W}$ side of Willcox Playa ( $32^{\circ} 5^{\prime} \mathrm{N}$ Lat, $109^{\circ} 55^{\prime} \mathrm{W}$ Long), Cochise County, Arizona. Coll. 1963 by J. F. Schreiber, Jr. and G. L. Pine, Univ. of Arizona; subm. by Schreiber. Sediment inclosing shells probably deposited in a pond or swamp. Comment: date is consistent with pond or swamp association of the shells, since A. Long (mss. in preparation) indicates that at that time the lake had just receded from a final high level above collection site. 
III. HYDROLOGIC SAMPLES

Seven samples of rain, spring and well water from which the dissolved $\mathrm{CO}_{2}$ and $\mathrm{HCO}_{3}$ were quantitatively removed and analyzed for $\mathrm{C}^{14}$ content. Purpose of study was not only to evaluate the initial concentration of $\mathrm{C}^{14}$ in the carbonate phase of precipitation, but also to determine rate of flow of ground water in mountainside aquifer systems by sampling the aquifer at several stations along the slopes and calculating the ages, assuming no mixing of waters of different age and no exchange with older carbonate. Such "high-resolution" carbon dating is possible in certain instances owing to rapid rise of atmospheric $\mathrm{C}^{14} / \mathrm{C}^{12}$ ratio, caused by thermonuclear explosions.

Data reported here as percent of modern $\mathrm{C}^{14}$ activity; age results along with complete hydrologic situations are to be reported elsewhere. All samples coll. 1963 and subm. by J. J. Sigalove, Isotopes Inc., Westwood, New Jersey.

Mt. Humphry, San Francisco Peaks series, Arizona

(ca. $35^{\circ} \mathrm{N}^{\text {Lat, }} 112^{\circ}$ W Long)

\begin{tabular}{|c|c|c|c|}
\hline & Location & Elevation $(\mathrm{ft})$ & $\%$ Modern \\
\hline $\begin{array}{c}\text { SI-63. } \\
\text { (composite } \\
\text { sample) }\end{array}$ & $\begin{array}{l}\text { Arbinean Canyon Spring } \\
\text { Flagstaff Canyon Spring }\end{array}$ & $\begin{array}{l}11,500 \\
10,500\end{array}$ & $134.5 \pm 3.1$ \\
\hline SI-64. & $\begin{array}{l}\text { Water Dept. cabin area, } \\
\text { Pipe Line Rd., Spring }\end{array}$ & 9440 & $123.9 \pm 2.9$ \\
\hline SI-65. & $\begin{array}{l}\text { Fish \& Game Comm. Spring } \\
\text { on Old Snow Bowl Rd. }\end{array}$ & 8500 & $114.7 \pm 1.3$ \\
\hline SI-66. I & Leroux Spring & 7600 & $116.7 \pm 1.4$ \\
\hline \multicolumn{4}{|c|}{$\begin{array}{l}\text { Mt. Graham, Pinaleno Mts., Arizona series } \\
\left(\text { ca. } 33^{\circ} \text { N Lat, } 110^{\circ} \text { W Long) }\right.\end{array}$} \\
\hline & Location & Elevation $(\mathrm{ft})$ & $\%$ Modern \\
\hline SI-61. & $\begin{array}{l}\text { Heliograph Station } \\
\text { Rain Water }\end{array}$ & 10,028 & $\mathbf{1 4 3 . 8} \pm \mathbf{5 . 5}$ \\
\hline SI-60. & $\begin{array}{l}\text { Columbine Ranger Station } \\
\text { Spring Water }\end{array}$ & 9500 & $123 \pm 11$ \\
\hline SI-62. & $\begin{array}{l}\text { Federal Prison Camp } \\
\text { Well Water at } 220^{\prime}\end{array}$ & 3400 & $98 \pm 3.9$ \\
\hline $\begin{array}{l}\text { Date lists: } \\
\text { Arizona I } \\
\text { Isotopes III } \\
\text { Michigan II } \\
\text { Michigan V } \\
\text { Michigan IX } \\
\text { Smithsonian I } \\
\text { UCLA III }\end{array}$ & $\begin{array}{l}\text { REFERENCES } \\
\text { Wise and Shutler, } 1958 \\
\text { Trautman, 1963 } \\
\text { Crane and Griffin, } 1958 \\
\text { Crane and Griffin, 1960 } \\
\text { Crane and Griffin, 1964 } \\
\text { I Sigalove and Long, 1964 } \\
\text { Fergusson and Libby, 1964 }\end{array}$ & & \\
\hline
\end{tabular}


Berger, R., Horney, A. G., Libby, W. F., 1964, Radiocarbon dating of bone and shell from their organic components: Science, v. 144, p. 999-1001.

Campbell, J. M., 1961, The Tuktu Complex of Anaktuvuk Pass: Anthropol. Papers, Univ. Alaska, v. 9, no. 2, p. 61-80.

Crane, H. R., and Griffin, J. B., 1958, University of Michigan radiocarbon dates II: Science, v. 127 , p. $1098-1105$.

v. 127, 1960, University of Michigan radiocarbon dates V: Am. Jour. Sci. Radioc. Supp., v. 2, p. $31-48$

Fergusson, G. J., and Libby, W. F., 1964, UCLA radiocarbon dates III: Radiocarbon, v. 6, p. 318-339.

Libby, W. F., 1955, Radiocarbon Dating, 2nd ed.: Univ. of Chicago Press.

Meggers, B. J., and Evans, C., 1962, The Machalilla Culture: An early formative complex on the Ecuadorian coast: Am. Antiquity, v. 28, no. 2, p. 186-192.

Megrers, B. J., Evans, C.. and Estrada, E., 1965, The early formative period of coastal Ecuador: The Valdivia and Machalilla phases: Bull. U. S. Nat. Mus., in press.

Sigalove, J. J., and Long, Austin, 1964, Smithsonian Institution radiocarbon measurements I: Radiocarbon, v. 6, p. 182-188.

Trautman, M. A., 1963, Isotopes, Inc., radiocarbon measurements III: Radiocarbon, v. 5, p. 62-79.

Wise, E. N., and Shutler, Dick, Jr., 1958, University of Arizona radiocarbon dates: Science, v. 127 , p. $72-74$. 